\title{
Effects of Seed Tuber Size and Plant Population on Seed Tuber Yield of Potato (Solanum Tuberosum L.) in Central Ethiopia
}

\author{
Zebenay Dagne $^{1^{*}} \quad$ Nigussie Dechassa $^{2} \quad$ Wassu Mohammed $^{2}$ \\ 1.Ethiopian Institute of Agriculture Research (EIAR), Holetta Research Centre, P. O. Box 2003 Addis Ababa, \\ Ethiopia \\ 2.Haramaya University College of agriculture and environmental sciences, school of plant sciences P.O. Box
} 138 Dire Dawa, Ethiopia

\begin{abstract}
Optimizing plant density and seed tuber sizes are the most important agronomic management practices in seed production of potato due to their effects on seed cost and seed tuber yields. A field experiment was conducted under irrigation during in 2014 at Holetta, Ethiopia with the objective of elucidating the effect of varied plant spacing and seed tuber sizes on seed tuber yield production. The results of analysis of variance (ANOVA) indicated that seed tuber size and plant spacing significantly $(\mathrm{P}<0.05)$ influenced on average tuber weight, number of tubers and tuber yield in each seed size categories, seed tuber costs. Highest tuber yield were obtained at closer plant spacing and from medium and large seed tuber sizes whereas the lowest tuber yield were obtained at wider plant spacing and from small seed tuber sizes. The highest numbers of tubers were obtained from large seed tuber sizes and plants grown at closer plant spacing of $50 \times 20,50 \times 30$ and $60 \times 20 \mathrm{~cm}$ produced highest tuber number. Plant spacing $60 \times 20 \mathrm{~cm}$ and medium-sized tubers $(35-45 \mathrm{~mm})$ led to the production of the highest seed tuber yield and appropriate for seed tuber yield production by considering better income, seed saving and intercultural operations. Keywords: Seed tuber size, Plant population, Seed tuber yield, Seed cost
\end{abstract}

DOI: $10.7176 / \mathrm{JNSR} / 9-3-08$

\section{INTRODUCTION}

Potato is graded as a high potential food security and cash crop because of its ability to provide a high yield of high quality product per unit input with a shorter crop cycle (mostly $<120$ days) compared to major cereal crops (Berga et al., 1992, Adane et al., 2010). Ethiopia has possibly the greatest potential for potato production and 70 percent its arable land mainly in highland areas above $1500 \mathrm{~m}$ believed suitable for potato production (Endale and Gebremedhin, 2001 and Gebremedhin et al., 2008). Although Ethiopia is endowed with suitable climatic and edaphic conditions the annual production of potato in Ethiopia is low (about 932,701 tons) and the national average yield is 13.799 tons/ha, which is very low compared to the world's average of 32.564 tons/ha (FAOSTAT, 2017).

Seed potato is one of the most important ingredients for successful potato production (Lacha et al., 2012). A reliable supply of good quality seed is crucial to the development of the potato subsector. Availability of seed remains one of the main constraints to the large scale adoption of research-bred or research-derived improved varieties (Lutaladio et al., 2009). Seed tuber size is an important factor to decide the seed per unit area because it affects total yield and graded or marketable tuber yields, particularly small tuber size increasing with increased size of the mother tuber (seed). The other dimension of interest for determining plant population and use of optimum spacing is the high seed rate required in potato production associated cost of seed which may account for up 50\% of total production cost (Gebremedhin et al., 2008).

A number of production problems that account for such low yields are unavailability and high cost of seed tubers, lack of well adapted cultivars, inappropriate agronomic practices, diseases, insect pests and inadequate storage (Bereke, 1994). The optimizing of plant density is one of the most important agronomic practices of potato production, because it affects seed cost, plant development, yield and quality of the crop (Bussan et al., 2007). The overall potato seed quality is affected by purity, genetic quality, health, size, physical damage and physiological age (Adane et al., 2010).

In all areas of Ethiopia, there is no separate plot and management for ware and seed potato production. Mostly, potato tubers are sorted into ware and seed immediately after harvest (Adane et al., 2010). For most potato producers seed potato is usually considered as the by-product of ware potato. Among the Ethiopian smallholder farmers in all areas, it is a common practice to save tubers for seed that are too small and inferior to be sold for consumption (Mulatu et al., 2005, Gildemacher et al. 2007 and Adane et al., 2010).

Potato seed tuber size and plant spacing in central Ethiopia in particular and in the country in general has not been given much emphasis in production higher seed tuber yields of appropriate seed tuber size and considering seed costs. Therefore, the objective of this study was to determine optimum tuber size and plant density for maximum tuber seed production and to evaluate cost and return among different tuber sizes.

MATERIALS AND METHODS

The study was conducted under irrigation during the year 2014 cropping season in off season at Holetta central 
highlands of Ethiopia. Holetta is situated at an altitude of 2400 meters above sea level at $9^{0} \mathrm{~N}$ latitude and $38^{\circ} 29^{\circ} \mathrm{E}$ longitude, and is located 40km West of Addis Ababa along the Ambo road. The average annual maximum and minimum temperature is $22.1 \mathrm{C}^{\circ}$ and $6.2 \mathrm{C}^{\circ}$ respectively. The soil type in the area is predominantly Nitosol which is characterized with average organic matter (AOM) content of $1.8 \%$, Nitrogen $0.17 \%$, Phosphorous $4.55 \mathrm{ppm}$ and Potassium 1.12 Meq/100gm of soil and pH 5.24 (HARC, 2004).

The treatments consisted of four tuber seed sizes in millimeter $(\mathrm{mm})(25-34,35-45,46-55$ and $>56 \mathrm{~mm})$ and five plant spacing $(75 \times 30 \mathrm{~cm}, 60 \times 30 \mathrm{~cm}, 60 \times 20 \mathrm{~cm}, 50 \times 30 \mathrm{~cm}$ and $50 \mathrm{~cm} \times 20 \mathrm{~cm})$. The experiment was laid out as a completely randomized block design (RCBD) in a factorial arrangement and replicated three times per treatment.

Data were subjected to analysis of variance (ANOVA) using the General Linear Model of the SAS statistical package (SAS, 2007) version 9.1. All significant pairs of treatment means were compared using the Least Significant Difference Test (LSD) at 5\% level of significance.

\section{Data Collection and Measurement}

Pre-planting: Average tuber size $(\mathrm{mm})$ and Average weight of tuber $(\mathrm{g})$, tuber number and yield in each seed tuber sizes, Gross average tuber yield $\left(\mathrm{kgha}^{-1}\right)$ (AVY), Adjusted yield (ADY), Gross field benefit (GFB), Total cost, and Net benefit (NB).

Data were subjected to analysis of variance (ANOVA) using the General Linear Model of the SAS statistical package (SAS, 2007) version 9.1. All significant pairs of treatment means were compared using the Least Significant Difference Test (LSD) at 5\% level of significance. Partial budget analysis was conducted as indicated in CIMMYT (1988) training manual.

\section{Results and Discussion}

Pre-planting data of experimental materials: Pre-planting data for seed tubers that average tuber weight (g) was increased as tuber size increased. Large seed tuber sizes $(>56 \mathrm{~mm})$ had the highest weight of tubers which was higher than $25-34 \mathrm{~mm}, 35-45 \mathrm{~mm}$ and $46-55 \mathrm{~mm}$ by about $84.16,68.66$ and $47.37 \%$, respectively. Average tuber weight increased when seed tuber sizes also increased from small to large seed tuber sizes (table 1). The preplanting data for seed tubers showed that average tuber size of tubers increased as tuber size increased. Average tuber size showed the increased trend towards the large seed tuber size where seed tubers size $>56 \mathrm{~mm}$ had highest average tuber size greater than $25-34 \mathrm{~mm}, 35-45 \mathrm{~mm}$ and $46-55 \mathrm{~mm}$ by about $53.1,37.6$ and $21.2 \%$, respectively. Table 1. Pre-planting data of experimental materials in each seed tuber sizes category

\begin{tabular}{|c|c|c|}
\hline \multirow{2}{*}{ Tuber size } & \multicolumn{2}{|c|}{ Pre planting data } \\
\cline { 2 - 3 } 남 & Average tuber size $(\mathrm{mm})$ & Average Tuber weight $(\mathrm{g})$ \\
\hline $35-34 \mathrm{~mm}$ & 29.25 & 26.92 \\
\hline $46-55 \mathrm{~mm}$ & 39.00 & 44.62 \\
\hline$>56 \mathrm{~mm}$ & 49.25 & 83.33 \\
\hline
\end{tabular}

Average tuber weight (g): From the analysis of the variance, seed tuber sizes and plant spacing showed highly significant difference $(\mathrm{P}<0.01)$ on average tuber weight (Table 2). Highest average tuber weight (119.61 g) was recorded for plants grown from $35-45 \mathrm{~mm}$ seed tuber sizes and at $75 \times 30 \mathrm{~cm}$ plant spacing treatment combinations this might be due to medium seed tuber sizes produced of optimum number of stems and wider plant spacing had less resource competitions they get high potential of resources whereas lowest average tuber weight $(55.91 \mathrm{~g})$ was obtained at $50 \times 20 \mathrm{~cm}$ plant spacing and $>56 \mathrm{~mm}$ seed tuber sizes treatment combinations. The present result agreed with the finding of Berga et al. (1992) that average tuber weight decreased with an increase in mother tuber size. Similarly, Zabihi-Mahmoodabad et al. (2010) reported that increase in density probably causes the increase in competition between and within plants and hence, leads to decrease in availability of nutrients to each plant and consequently, results in decline of mean tuber weight. The production of higher average tuber weight at wider plant spacing as compared to closer plant spacing was also reported by other authors (Bussan et al., 2007, Gulluoglu and Arroglu, 2009 and Harnet et al., 2014). 
Table 2. Average tuber weight as influenced by the interaction factors of plant spacing and seed tuber size

\begin{tabular}{llllll}
\hline & Plant spacing & & & \\
\cline { 2 - 6 } Tuber size & $75 \times 30 \mathrm{~cm}$ & $60 \times 30 \mathrm{~cm}$ & $60 \times 20 \mathrm{~cm}$ & $50 \times 30 \mathrm{~cm}$ & $50 \times 20 \mathrm{~cm}$ \\
\hline$>56 \mathrm{~mm}$ & $84.63 \mathrm{c}$ & $76.86 \mathrm{~cd}$ & $66.69 \mathrm{defg}$ & $63.36 \mathrm{fgh}$ & $55.91 \mathrm{~h}$ \\
$46-55 \mathrm{~mm}$ & $104.35 \mathrm{~b}$ & $76.44 \mathrm{~cd}$ & $71.09 \mathrm{defg}$ & $69.93 \mathrm{defgh}$ & $65.74 \mathrm{efgh}$ \\
$35-45 \mathrm{~mm}$ & $119.61 \mathrm{a}$ & $105.16 \mathrm{~b}$ & $76.99 \mathrm{~cd}$ & $72.92 \mathrm{def}$ & $66.99 \mathrm{defg}$ \\
$25-34 \mathrm{~mm}$ & $75.69 \mathrm{cde}$ & $74.57 \mathrm{cde}$ & $69.16 \mathrm{efgh}$ & $62.06 \mathrm{gh}$ & $63.75 \mathrm{fgh}$ \\
$\mathrm{LSD} / 5 \% /$ & 11.55 & & & & \\
CV $/ \% /$ & 9.03 & & & & \\
\hline
\end{tabular}

Means followed by the same letter(s) within a row and column are not significantly different at $5 \%$ level of significance. $\mathrm{LSD}=$ least significant difference, $\mathrm{CV}=$ coefficient of variation

\section{Yield and number of Seed Tubers in Different Seed Size Categories}

Yield and number of large seed tuber size $(>\mathbf{5 6} \mathbf{m m})$ : The analysis of variance result showed that Belete variety was significantly $(\mathrm{P}<0.05)$ influenced in producing number and yield of large seed tuber size due to plant spacing and seed tuber size, but the two factors did not interact to influence the parameter (Table 3). The results showed maximum number and yield of large tuber size 144491 and $12.82 \mathrm{t} \mathrm{ha}^{-1}$ were obtained from plants spaced at $60 \mathrm{x}$ $30 \mathrm{~cm}$ whereas the lowest number and yield of large seed tuber size were obtained at plant spacing of $60 \mathrm{x} 20 \mathrm{~cm}$ and $50 \times 30$, respectively. Plants spaced at $60 \times 30 \mathrm{~cm}$ did not produce number of tubers and yields of large seed tuber size statistically different than plants spaced at $75 \times 30 \mathrm{~cm}$. Generally, numbers and yield of large tuber size per hectarewere increased as plants spaced wider than plants grown in narrower plant spacing. This might be due to the slight competition between plants for nutrients and growth factors that increased photosynthesis efficiency of plants and increased seed tuber sizes. This result agreed with the findings of Tesfaye et al. (2013) who reported that highest number of large tuber sizes was recorded at wider plant spacing due to minimum competition of plants, absorbed sufficient available resources and increased their photosynthesis efficiency that ultimately increased number of large seed tubers. Similarly, Gebremedhin et al. (2008) reported that more number of tubers with size grades of $30-40 \mathrm{~mm}$ and $>50 \mathrm{~mm}$ diameter were obtained from $60 \mathrm{~cm}$ and $75 \mathrm{~cm}$ inter-row spacing, respectively.

Based on the result the maximum number and yield of large seed tuber size 122363 and $12.28 \mathrm{t} \mathrm{ha}^{-1}$ were obtained when $46-55 \mathrm{~mm}$ and $35-45 \mathrm{~mm}$ seed tuber sizes were used as planting materials, respectively whereas the lowest number and yield was recorded from small seed tuber size $(25-34 \mathrm{~mm})$ were used as planting materials (Table 3). This due to medium size seed tubers produced optimum number of stems per tuber than large seed tuber size which had less resources competition between plants which lead to the production of high number and yield of large seed tuber sizes. Similarly, medium seed tuber sizes had high food reserves than small seed tuber size which led to produce high number and yield of large tuber sizes. This result agrees with the finding of Lung'aho et al. (2007) who reported that too big seed tubers will result in the production of too many stems and tubers, which will compete for growth factors in the soil and become too small. Thus, such tubers will be unmarketable for use as either ware or seed potato. On the other hand, too small seed tubers will have small number of stems, which will produce only a few tubers, thereby reducing yield.

Yield and number of medium seed tuber size (46-55mm): Plant spacing and seed tuber size had highly significantly $(\mathrm{p}<0.01)$ influenced on number and yield of medium seed tuber sizes, but the two factors did not interact to influence on numbers and yield of medium seed tuber sizes (Table 3). Significantly highest number and yield of medium seed tuber sizes 214167 and $12.37 \mathrm{tha}^{-1}$ were obtained at $50 \times 20 \mathrm{~cm}$ and $60 \times 30 \mathrm{~cm}$ plant spacing, respectively whereas the lowest number and yield of medium seed tuber size was obtained at $75 \times 30 \mathrm{~cm}$ and $50 \mathrm{x}$ $30 \mathrm{~cm}$ plant spacing, respectively (Table 3). Plant spacing of $50 \times 20 \mathrm{~cm}$ plant spacing did not statistically difference with $60 \times 30 \mathrm{~cm}, 60 \times 20 \mathrm{~cm}$ and $50 \times 30 \mathrm{~cm}$ plant spacing to produce high number and yield of medium seed tuber sizes. When plant density increased the number of medium seed tuber sizes increased. However, this is reversed when high yield of medium seed tuber sizes produced where plants grown at wider plant spacing produced high yield of medium seed tuber sizes than plants at closer plant spacing. This might beat closer plant spacing had high number of hills per unit area which lead to produce higher number of medium seed tuber sizes than wider plant spacing. On the other hand at closer plant spacing there could be strong competition between plants for nutrients and growth factors which lead to produce low yield of medium seed tuber sizes. This study agreed with Wiersema, (1987) results who reported that the number of tubers produced depends on the completion of among stems for growth factors, at lower stem densities competition is less, which results a greater tuber number of per stem, but also in a smaller number of tubers per unit area.

The result showed that maximum number and yield of medium seed tuber sizes 223659 and $12.83 \mathrm{tha}^{-1} \mathrm{was}$ obtained when large $(>56 \mathrm{~mm})$ and medium $(46-55 \mathrm{~mm})$ seed tuber sizes, respectively were used as planting materials (Table 3 ). Large seed tuber sizes $(>56 \mathrm{~mm})$ did not statistically difference with $46-55 \mathrm{~mm}$ and $35-45 \mathrm{~mm}$ seed tuber size to produce high number and yield of medium seed tuber sizes. Number of medium tuber seed sizes increased when increasing seed tuber sizes from small to large seed tuber sizes. This due to large and medium seed 
tuber sizes had high number of eyes per tuber and had high probability to produced high number of main stems per hill than small seed tuber size which lead to produce high number medium seed tuber sizes. Similarly, large and medium seed tuber sizes had higher food reserves than small seed tuber sizes which lead to produce high yield of medium seed tuber sizes. This result consistented with Rajadurai (1994) reported that more tubers were formed from larger seed tubers and the number increased from small seed size to large seed size. Similarly, Khalafalla (2001) reported that large seed size gave more number of tubers/plant than small seed sizes.

Yield and number of medium seed tuber sizes (35-45mm): Plant spacing and seed tuber size had significantly $(\mathrm{p}<0.05)$ affected numbers and yield of medium seed tuber sizes (Table 3$)$. The result showed that plants grown at $50 \times 20 \mathrm{~cm}$ plant spacing produced 242667 and $11.82 \mathrm{t} \mathrm{ha}^{-1}$ number and yield of medium seed tuber sizes whereas low number and yield of medium seed tuber sizes 157157 and $6.51 \mathrm{t} \mathrm{ha}^{-1}$ was recorded at $75 \mathrm{x} 30 \mathrm{~cm}$ plant spacing (Table 3). Plant spacing of $50 \times 20 \mathrm{~cm}$ did not statistically difference with plant spacing of $60 \times 20 \mathrm{~cm}$ and $50 \times 30 \mathrm{~cm}$ to produce numbers of medium seed tuber sizes. At closer plant spacing produced high number and yield of medium seed tuber sizes than wider plant spacing. This due to closer plant spacing there could be high competition of resources between plants for nutrients and growth factors which lead to produce high numbers and yield of medium seed tuber sizes. This result agreed with Tesfaye et al. (2013) who reported that the highest number of medium sized potato tubers was obtained at closer plant spacing had higher competition among plants for resources. The highest number of medium seed tuber sizes $(35-45 \mathrm{~mm})$ was obtained at $60 \times 20 \mathrm{~cm}, 50 \times 30 \times$ $30 \mathrm{~cm}$ and $50 \times 20 \mathrm{~cm}$ plant spacing. Therefore, from the results of this study, it appears that plant spacing of $60 \mathrm{x}$ $20 \mathrm{~cm}$ is appropriate for seed tuber production by considering better seed saving and intercultural operations. Accordingly, for seed potato production, the results of this are consistented with the established recommendation given by EARO (2004). Endale and Gebremedihen (2001) also indicated that decreasing row width below $60 \mathrm{~cm}$ can bring in cultural problems in addition to almost doubling the seed rate cost.

Significantly maximum number and yield of medium seed tuber sizes (35-45mm) 236652 and $10.7 \mathrm{t} \mathrm{ha}^{-1}$, respectively was obtained when large seed tuber size $(>56 \mathrm{~mm})$ used as a planting material whereas the lowest number and yield of medium seed tuber sizes were obtained from small seed tuber size (Table 3 ). This due to large seed tuber size produced high number of stems per tuber than medium and small seed tuber sizes which had high resource competitions between plants which lead to produce high number and yield of medium seed tuber sizes $(35-45 \mathrm{~mm})$. This result agreed with Khalafalla (2001) reported that large seed size gave more number of tubers/plant than small seed sizes. Similarly, Berga et al (1992a) reported that tuber number increased significantly with increase seed tuber size. The highest numbers of medium seed tuber sizes $(35-45 \mathrm{~mm})$ were obtained from large $(>56 \mathrm{~mm})$ and medium $(35-45 \mathrm{~mm}$ and $46-55 \mathrm{~mm})$ seed tuber sizes. Therefore, from the results of this study, it appears that a medium seed tuber size $(35-45 \mathrm{~mm})$ is appropriate for seed tuber production by considering production cost. Accordingly, for seed potato production, the results of the present investigation were consistent with the established recommendation given by EARO (2004).

Yield and number of small seed tuber sizes $(\mathbf{2 5 - 3 4 m m ) : ~ t h e ~ a n a l y s i s ~ o f ~ v a r i a n c e ~ s h o w e d ~ t h a t ~ t h e ~ m a i n ~ f a c t o r s ~}$ of seed tuber size and plant spacing had highly significantly $(\mathrm{p}<0.01)$ influenced on yield of medium tuber size, but the two factors did not interact to influence the number and yield of small seed tuber sizes. Maximum number and yield of small seed tuber sizes 210833 and $4.63 \mathrm{t} \mathrm{ha}^{-1}$, respectively was recorded at plant spacing of $50 \times 20$ $\mathrm{cm}$ whereas lowest number and yield of small seed tuber sizes 74722 and $1.49 \mathrm{t} \mathrm{ha}^{-1}$ was obtained at plant spacing of $75 \times 30 \mathrm{~cm}$. At closer plant spacing produced high number and yield of small seed tuber sizes than wider plant spacing. This due to closer plant spacing there could be strong competition between plants for nutrient and growth factors which lead to produce high number and yield of small seed tuber sizes. This result agreed with the finding of Berga et al. (1992a) reported that total number and seed sizes numbers (smaller tubers) increased with closer spacing. Similarly, Tesfaye et al. (2013) reported that the highest number of small tubers was obtained at closer plant spacing whereas the lowest number of small potato tubers was found at wider plant spacing.

Significantly high number and yield of small seed tuber sizes 175926 and $10.7 \mathrm{t} \mathrm{ha}^{-1}$, respectively was obtained from large seed tuber size $(>56 \mathrm{~mm})$ whereas lowest number and yield of small seed tuber size was recorded from small seed tuber sizes (Table 3). When increased the seed tuber sizes from small to large seed tuber sizes yield and number of small seed tuber sizes also increased. This due to large seed tuber sizes produced high number of stems per tuber than medium and small seed tuber sizes which had high competition of resources between stem (tubers) which lead to produced high number and yield of small seed tuber sizes. This result agreed with the results reported by Rajadrai (1994) that number of tubers per plant increased with increasing seed tuber size and large size seed tubers produced significantly more number of tubers. 
Table 3. Yield $\left(\mathrm{t} \mathrm{ha}^{-1}\right)$ and Number of different seed tuber sizes as influenced by plant spacing and seed tuber size

\begin{tabular}{|l|l|l|l|l|l|l|l|l|}
\hline \multirow{2}{*}{ Spacing } & \multicolumn{9}{|c|}{ Parameter } \\
\cline { 2 - 9 } & \multicolumn{2}{|c|}{$>56 \mathrm{~mm}$} & \multicolumn{2}{|c|}{$46-55 \mathrm{~mm}$} & \multicolumn{2}{c|}{$35-45 \mathrm{~mm}$} & \multicolumn{2}{c|}{$25-34 \mathrm{~mm}$} \\
\cline { 2 - 9 } & Number & Yield & Number & Yield & Number & Yield & Number & Yield \\
\hline $75 \mathrm{~cm} \times 30 \mathrm{~cm}$ & $139278 \mathrm{ab}$ & $12.54 \mathrm{a}$ & $146741 \mathrm{~b}$ & $11.66 \mathrm{ab}$ & $157157 \mathrm{~b}$ & $6.51 \mathrm{~d}$ & $74722 \mathrm{c}$ & $1.49 \mathrm{c}$ \\
\hline $60 \mathrm{~cm} \times 30 \mathrm{~cm}$ & $144491 \mathrm{a}$ & $12.82 \mathrm{a}$ & $205278 \mathrm{a}$ & $12.37 \mathrm{a}$ & $180370 \mathrm{~b}$ & $7.28 \mathrm{~d}$ & $98148 \mathrm{c}$ & $2.04 \mathrm{c}$ \\
\hline $60 \mathrm{~cm} \times 20 \mathrm{~cm}$ & $106667 \mathrm{c}$ & $9.58 \mathrm{~b}$ & $205278 \mathrm{a}$ & $11.65 \mathrm{ab}$ & $241111 \mathrm{a}$ & $10.43 \mathrm{~b}$ & $185833 \mathrm{ab}$ & $3.91 \mathrm{ab}$ \\
\hline $50 \mathrm{~cm} \times 30 \mathrm{~cm}$ & $114722 \mathrm{c}$ & $8.71 \mathrm{~b}$ & $201167 \mathrm{a}$ & $9.24 \mathrm{c}$ & $231389 \mathrm{a}$ & $8.99 \mathrm{c}$ & $165833 \mathrm{~b}$ & $3.40 \mathrm{~b}$ \\
\hline $50 \mathrm{~cm} \times 20 \mathrm{~cm}$ & $117583 \mathrm{bc}$ & $9.21 \mathrm{~b}$ & $214167 \mathrm{a}$ & $10.25 \mathrm{bc}$ & $242667 \mathrm{a}$ & $11.82 \mathrm{a}$ & $210833 \mathrm{a}$ & $4.63 \mathrm{a}$ \\
\hline LSD $(5 \%)$ & 22733 & 1.47 & 24296 & 1.75 & 31141 & 1.34 & 26873 & 0.84 \\
\hline Tuber size & & & & & & & & \\
\hline$>56 \mathrm{~mm}$ & $122363 \mathrm{~b}$ & $9.37 \mathrm{~b}$ & $223659 \mathrm{a}$ & $12.14 \mathrm{ab}$ & $236652 \mathrm{a}$ & $10.70 \mathrm{a}$ & $175926 \mathrm{a}$ & $3.77 \mathrm{a}$ \\
\hline $45-55 \mathrm{~mm}$ & $149556 \mathrm{a}$ & $11.10 \mathrm{a}$ & $207185 \mathrm{a}$ & $12.83 \mathrm{a}$ & $213356 \mathrm{a}$ & $9.33 \mathrm{~b}$ & $148370 \mathrm{~b}$ & $3.25 \mathrm{ab}$ \\
\hline $35-45 \mathrm{~mm}$ & $147333 \mathrm{a}$ & $12.28 \mathrm{a}$ & $203926 \mathrm{a}$ & $10.69 \mathrm{~b}$ & $209185 \mathrm{ab}$ & $8.26 \mathrm{bc}$ & $127481 \mathrm{~b}$ & $2.55 \mathrm{~b}$ \\
\hline $25-34 \mathrm{~mm}$ & $78941 \mathrm{c}$ & $7.54 \mathrm{c}$ & $143333 \mathrm{~b}$ & $8.47 \mathrm{c}$ & $182963 \mathrm{~b}$ & $7.72 \mathrm{c}$ & $136519 \mathrm{~b}$ & $2.81 \mathrm{~b}$ \\
\hline LSD $(5 \%)$ & 20333 & 1.32 & 21731 & 1.56 & 27853 & 1.19 & 24036 & 0.75 \\
\hline CV $(\%)$ & 22.08 & 16.84 & 15.11 & 19.16 & 17.90 & 17.97 & 22.11 & 32.77 \\
\hline
\end{tabular}

Means followed by the same letter(s) within a column in each factor are not significantly different at $5 \%$ level of significance. $\mathrm{LSD}=$ least significant difference, $\mathrm{CV}=$ coefficient of variation.

Partial Budget Analysis: The highest marketable tuber yield 389.70, 385.40 and 384.20qt ha-1 was obtained at $60 \times 30 \mathrm{~cm}$ plant spacing and medium seed tuber sizes $(35-45 \mathrm{~mm}), 60 \times 30 \mathrm{~cm}$ plant spacing and large seed tuber sizes $(>56 \mathrm{~mm})$ and $50 \times 20 \mathrm{~cm}$ plant spacing and large seed tuber size $(>56 \mathrm{~mm})$ treatment combinations, respectively. Similarly, highest profit or gain 57551 was obtained at plant spacing of $60 \times 30 \mathrm{~cm}$ and medium seed tuber size $(35-45 \mathrm{~mm})$ treatment combinations whereas the lowest income -13574 birr was obtained from large seed tuber sizes $(>56 \mathrm{~mm})$ and plant spacing of $50 \times 20 \mathrm{~cm}$ treatment combinations (Table 4).

On this study showed that potato production at closer plant spacing of $50 \times 20 \mathrm{~cm}$ and $60 \times 20 \mathrm{~cm}$ by using large seed tuber size $(>56 \mathrm{~mm})$ is not profitable than other seed tuber sizes and plant spacing treatment combinations (Table 4). In general, from the cost benefit analysis; the production cost increased with increasing in seed tuber size, hence resulting low economic return. The high net gain from above mentioned treatments could be mainly attributed used medium seed tuber sizes while the low net gain was attributed used large seed tuber size. Based on yield and income or gain, plant spacing $60 \times 30 \mathrm{~cm}$ under seed tubers size of $35-45 \mathrm{~mm}$ are recommended for potato production over than other seed tubers size and plant spacing combinations farmers can use to maximize their income or gain instead used the other seed tuber sizes and plant spacing.

Table 4. Interaction of seed tuber size and plant spacing on economic analysis of marketable tuber yield

\begin{tabular}{|c|c|c|c|c|c|c|c|}
\hline \multirow[t]{2}{*}{ spacing } & \multirow[t]{2}{*}{ Tuber size } & \multirow{2}{*}{$\begin{array}{c}\text { Seed } \\
\left(\mathrm{qt} \mathrm{ha}^{-1}\right)\end{array}$} & \multirow{2}{*}{$\begin{array}{l}\text { Seed cost } \\
\text { (Birr) }\end{array}$} & \multirow{2}{*}{$\begin{array}{c}\text { AvY (qtha- } \\
1 \text { ) }\end{array}$} & \multirow{2}{*}{$\frac{\mathrm{AdY}}{\left.(\mathrm{qt} \mathrm{ha})^{1}\right)}$} & \multirow{2}{*}{$\begin{array}{c}\text { Total } \\
\text { income }\end{array}$} & \multirow{2}{*}{$\begin{array}{c}\text { Net gain } \\
\text { (Birr) }\end{array}$} \\
\hline & & & & & & & \\
\hline $75 \mathrm{~cm} 30 \mathrm{~cm}$ & $>56 \mathrm{~mm}$ & 73.54 & 36770 & 326.2 & 293.58 & 58716 & 21946 \\
\hline & $46-55 \mathrm{~mm}$ & 39.07 & 19535 & 345.4 & 310.86 & 62172 & 42637 \\
\hline & $35-45 \mathrm{~mm}$ & 26.46 & 13230 & 303.2 & 272.88 & 54576 & 41346 \\
\hline & $25-34 \mathrm{~mm}$ & 12.56 & 6280 & 257.8 & 232.02 & 46404 & 40124 \\
\hline $60 \mathrm{~cm} \times 30 \mathrm{~cm}$ & $>56 \mathrm{~mm}$ & 99.7 & 49850 & 385.4 & 346.86 & 69372 & 19522 \\
\hline & $46-55 \mathrm{~mm}$ & 40.96 & 20480 & 349.6 & 314.64 & 62928 & 42448 \\
\hline & $35-45 \mathrm{~mm}$ & 25.19 & 12595 & 389.7 & 350.73 & 70146 & 57551 \\
\hline & $25-34 \mathrm{~mm}$ & 15.69 & 7845 & 235.4 & 211.86 & 42372 & 34527 \\
\hline $60 \mathrm{~cm} \times 20 \mathrm{~cm}$ & $>56 \mathrm{~mm}$ & 137.88 & 68940 & 367.4 & 330.66 & 66132 & -2808 \\
\hline & $46-55 \mathrm{~mm}$ & 73.26 & 36630 & 346 & 311.4 & 62280 & 25650 \\
\hline & $35-45 \mathrm{~mm}$ & 37.78 & 18890 & 347.8 & 313.02 & 62604 & 43714 \\
\hline & $25-34 \mathrm{~mm}$ & 23.54 & 11770 & 258.3 & 232.47 & 46494 & 34724 \\
\hline $50 \mathrm{~cm} \times 30 \mathrm{~cm}$ & $>56 \mathrm{~mm}$ & 110.31 & 55155 & 324.7 & 292.23 & 58446 & 3291 \\
\hline & $46-55 \mathrm{~mm}$ & 58.61 & 29305 & 336.1 & 302.49 & 60498 & 31193 \\
\hline & $35-45 \mathrm{~mm}$ & 39.69 & 19845 & 320.6 & 288.54 & 57708 & 37863 \\
\hline & $25-34 \mathrm{~mm}$ & 18.83 & 9415 & 214.2 & 192.78 & 38556 & 29141 \\
\hline $50 \mathrm{~cm} \times 20 \mathrm{~cm}$ & $>56 \mathrm{~mm}$ & 165.46 & 82730 & 384.2 & 345.78 & 69156 & -13574 \\
\hline & $46-55 \mathrm{~mm}$ & 73.72 & 36860 & 359.8 & 323.82 & 64764 & 27904 \\
\hline & $35-45 \mathrm{~mm}$ & 45.34 & 22670 & 329.2 & 296.28 & 59256 & 36586 \\
\hline & $25-34 \mathrm{~mm}$ & 28.25 & 14125 & 230.3 & 207.27 & 41454 & 27329 \\
\hline
\end{tabular}

$\left(\mathrm{AY} \mathrm{ha} \mathrm{h}^{-1}\right)=$ Gross average tuber yield and $\left(\mathrm{AdY} \mathrm{ha}^{-1}\right)=$ adjusted yield

During experimental period the price of seed $500 \mathrm{ETBqt}^{-1}$ and selling price during harvesting was $200 \mathrm{ETBqt}^{-1}$. 


\section{SUMMARY AND CONCLUSION:}

The present study revealed that plant spacing of $60 \times 30 \mathrm{~cm}, 60 \times 20 \mathrm{~cm}$ and $50 \times 20 \mathrm{~cm}$ resulted in the production of higher marketable number and tuber yield than the other spacing. However, the amount of seed to cover a given area has to be considered the spacing of $60 \times 30 \mathrm{~cm}$ more appropriate than the other two spacing's for ware potato production. Similarly, for seed production $60 \times 20 \mathrm{~cm}$ plant spacing was more appropriate seed tubers by considering better seed saving and intercultural operations. Large $(>56 \mathrm{~mm})$ and medium $(46-55 \mathrm{~mm})$ seed tuber sizes produced maximum marketable tuber yield but medium seed tuber sizes $(35-45 \mathrm{~mm})$ were appropriate seed production by considering the result of partial budget analysis.

\section{ACKNOWLEDGEMENT}

The authors would like to thank Ethiopian Institute Agricultural Research (EIAR) and Holetta Agricultural Research Center (HARC) for financing the MSc research.

\section{REFERENCE}

Adane, A., Meuwissen, M.P.M., Tesfaye, A., Lommen, W.J.M., Lansink, A.O., Tsegaye, A. and Struik, P.C. 2010. Analysis of seed potato systems in Ethiopia. Am. J. Pot Res, 87:537-552.

Adhikari, R.C. 2005. Performance of different size true potato seed seedling tubers at Khumaltar. Potato Research Program-NARC, Khumaltar-Lalitpur. Nepal Agric. Res. J. Vol. 6.

Bereke, T.T. 1994. The utilization of true potato seed (TPS) as an alternative method of potato production. Ph.D. Thesis, School of Graduate Studies of Wageningen University, the Netherlands.

Berga, L., Gebremedihin, W., Teriessa, J. and Bereke-Tsehai, T. 1992. Proceeding of $2^{\text {nd }}$ national horticultural workshop of Ethiopia, 1-3 December 1992. Potato agronomy research in Ethiopia in: Horticulture research and development in Ethiopia. Addis Ababa, Ethiopia.

Berga, L., Gebremedihin, W., Teriessa, J., Bereke-Tsehai, T. and Yaynu, H. 1992b. Proceeding of $2^{\text {nd }}$ national horticultural workshop of Ethiopia, 1-3 December 1992 Potato improvement research in Ethiopia in: Horticulture research and development in Ethiopia. Addis Ababa, Ethiopia.

Bohl, W.H. 2000. Seed piece size and spacing: effects on yield operating cost, Presented at the Idaho Potato Conference.

Bohl, W.H., Nolte. P., Kleinkopf, G.E., Thornton, M. K. 2000. Potato seed Management Seed Size and Age.

Bussan, A. J., Mitchell, P. D., Copas, M. E. and Drilias. M. J. 2007. Evaluation of the effect of density on potato yield and tuber size distribution. Crop science, 47: 2462-2472.

CIMMYT.1988. From agronomic data to farmers' recommendations: an economic training manual. Completely revised edition. Mexico, DF. 79p.

CSA (Central Statistical Agency of Ethiopia). 2013/14. Agricultural sample survey: Report on area and production of crops, Addis Ababa, Ethiopia, p 14.

EARO (Ethiopian Agricultural Research Organization). 2004. Ethiopian agricultural research organization directory of released crop varieties and their recommended cultural practices, Addis Ababa, Ethiopia.

Endale, G. and Gebremedhin, W.G. 2001. Effects of Spatial Arrangement on Tuber Yields of Some Potato Cultivars. African Crop Science Journal 9(1): 67-76.

FAOSTAT. 2017. Food and Agriculture Organization of the United Nations, for a world without hunger. Rome, Italy. http://faostat.fao.org /site/567/.

Gebremedhin, W., Kassaye, N., Atsede, S., Abebe, C. and Berga, L. 2012. Proceedings of the national workshop on seed potato tuber production and dissemination, 12-14 March 2012. Participatory potato seed production: experiences from West and Southwest Shewa, and Gurage Zones. Seed potato tuber production and dissemination experiences, challenges and prospects. Bahir Dar, Ethiopia

Gildemacher, P., Demo, P., Kinyae, P., Wakahiu, M., Nyongesa, M. and Zschocke, T. 2007. Select the best positive selection to improve farmers saved seed potatos trainers manual, Njoro, Kenya.

Gulluoglu, L. and Arioglu, H. 2009. Effects of seed size and in row spacing on growth and yield of early potato in a Mediterranean-type environment in Turkey. African Journal of Agricultural Research .4 (5): 535-541.

HARC (Holetta agricultural research center). 2004. Holetta research centre annual report, Holetta, Ethiopia.

Harnet, A., Derbew, B. and Gebremedhin, W. 2014. Effects of inter and intra row spacing on seed tuber yield and yield components of potato (Solanum tubersoum L.) at Ofla Woreda, Northern Ethiopia. Afr.J.Plant SCI. $8(6): 285-290$

Islam, M.S., Moonmoon, S., Islam, M.Z., Waliullah, H. and Hossain, M.S. 2012. Studies on seed size and spacing for optimum yield of potato in northern region of Bangladesh. Bangladesh J. Prog. Sci. \& Tech. 10(1): 113116.

Khalafalla, A.M. 2001.Effect of Plant density and seed size on growth and yield of Solanum potato in Khartoum State, Sudan. African Crop Science Journal 9 (1): 77-82.

Lacha G., Nigussie, D. and Firew M. 2012. Proceedings of the national workshop on seed potato tuber production 
and dissemination, 12-14 March 2012. Seed system analysis of potato in Guraghe Highlands. Seed potato tuber production and dissemination experiences, challenges and prospects. Bahir Dar, Ethiopia

Lung'aho, C., Lemaga, B., Nyongesa, M., Gildemacher, P., Kinyae, P., Demo, P. and Kabira, J. 2007. Commercial seed potato production in eastern and central Africa. Kenya agricultural research institute. pp.140.

Lutaladio, N., Ortiz, O., Haverkort, A. and Caldiz, D. 2009. Sustainable potato production guidelines for developing countries. Food and agriculture organization of the United Nations Rome, Italy.

Masarirambi, M.T., Mandisodza, F.C., Mashingaidze, A.B. and Bhebhe, E. 2012. Influence of plant population and seed tuber size on growth and yield components of potato (Solanum tuberosum). Int. J. Agric. Biol. 14: $545-549$.

MoARD (Ministry of Agriculture and Rural Development). 2011. Animal and plant health regulatory directorate. Crop variety register issue No. 12. Addis Ababa, Ethiopia.

Mulatu., E., Osman, I. and Etenesh, B. 2005. Improving potato seed tuber quality and producers' livelihoods in Hararghe, Eastern Ethiopia. Journal of New Seeds 7(3): 31-56.

Rajadurai, S.1994. Effects of seed tuber size and planting space on growth, yield and tuber size distribution of potato (solanum tuberosum L.) in irrigated red-yellow latosols of the dry zone. J. Natn. sci. coun. sri Lanka 22(2):115-123.

SAS (Statistical Analysis Software). 2007. Stat. Jahrbuch tuber Ernahrung, Landwirtschaft und Forsten In German, Landwirtschaftsverlag Munster-Hiltrup, Germany, 2008.

Sen, D., Rakshit, A. and Ghosh, D. C. 2013. Effect of transplanting dates and plant population on growth parameters of potato (solanum tuberosum L.) raised from true potato seed (tps). cercetări agronomice în moldova vol. xlvii , no. 1 (157)

Struik, P. C., and Wiersema, S. G. 1999. Seed potato technology. Wageningen pers, wageningen, Netherlands.

Tesfa, B. 2012. Influence of plant spacing on seed tuber production of potato (Solanum tuberosum L.) cultivars grown in Eastern Ethiopia. MSc. Thesis submitted to school of plant sciences, Haramaya University, Ethiopia.

Tesfaye, A. 2007. Proceeding of $1^{\text {st }}$ Amhara Regional workshop on potato research and development. Achievements and transfer experiences and future directions 20-21 December 2007. The contribution of potato in addressing food security agenda of millennium development goal. current and future scenario. Bahir Dar, Ethiopia

Tesfaye, G., Derbew, B. and Solomon, T. 2013. Combined effects of plant spacing and time of earthing up on tuber quality parameters of potato (solanum tuberosum L.) at Degem district, North Showa zone of Oromia regional state. Asian Jouurnalof Crop Science 5(1):24-32.

Thornton, M., Pavek, M. and Bohl, W.H. 2007. Importance of tuber set and bulking rate. Idaho Potato Conference, India.

Wiersema, S.G. 1987. Effects of stem density on potato production. Technical information bulletin international potato center, Lima, peru.16pp. (third edition, revised).

Zamil, M.F., Rahma, M.M., Rabbani, M.G. and Khatun, T. 2010. Combined effects of nitrogen and plant spacing on the growth and yield of potato with economic performance. Bangladesh Res.Pub.J.(3):1062-1070. 